\title{
EVALUATION OF TILLAGE AND PLANTING SYSTEM OF UPLAND CROPS DURING DRY SEASON
}

\author{
H. M. K. Bashar ${ }^{1}$, G. N. Hasan 2 , J. U. Sarker ${ }^{3}$, F. Rahaman ${ }^{2}$ and I. Uddin ${ }^{4}$ \\ ${ }^{1}$ Senior scientific Officer, On-Farm Research Division, Bangladesh Agricultural Research Institute, Bangladesh \\ ${ }^{2}$ Scientific Officer, On-Farm Research Division, Bangladesh Agricultural Research Institute, Bangladesh \\ ${ }^{3}$ Director, T \& C wing, BARI, Gazipur, Bangladesh \\ ${ }^{4}$ Senior Scientific Officer, Soil Resources Development Institute, Bangladesh \\ Correspondence author: basharlaboni@yahoo.com
}

Key words: Tillage, planting system, upland crop

\begin{abstract}
Upland crops cultivation in the south central coastal area of Bangladesh is limited due to heavy textured soil with late recession of flood water and early flash flood by heavy rainfall The present study was designed to find out tillage requirement and suitable planting system for upland crops.. Number of tillage (two to four passes) was evaluated along with two planting systems viz., bed and flat planting systems using four crops like, tomato (Solanum lycopersicum L.), brinjal (S. melongena L.), bitter gourd (Momordica charantia L.) and cucumber (Cucumis sativus L.) The crops showed that increased fruit yield with increasing number of tillage in both planting system. But bed planting system produced higher fruit yield (brinjal $67.73 \mathrm{t} \mathrm{ha} \mathrm{a}^{-1}$, tomato $85.33 \mathrm{t} \mathrm{ha}^{-1}$, bittergourd $41.8 \mathrm{t} \mathrm{ha}^{-1}$ and cucumber 25.8 $\mathrm{t} \mathrm{ha}^{-1}$ ) than flat planting system. Another, bed planting helped to escape crop damage by early heavy rainfall in all crops.
\end{abstract}

\section{Introduction}

Bangladesh has a tropical monsoon climate. Organic-matter content in soil is dependent on agroclimatic conditions and is difficult to conserve at a high level in tropical and subtropical conditions (Bhuiya, 1987; BARC, 2005). Ecological conditions do not favor practicing multiple cropping or achieving high yields. Farmers growing upland crops risking climate vagaries very often are frustrated with crop failure due to inundation. Low cropping intensity occurs due to tidal submergence of cropped land during monsoon, delay in soil drying process, lack of irrigation in dry season and early tidal water made the tidal ecosystem in the southern region of Bangladesh less productive with least diversification of cropping. Production of vegetables and fruits is the least. Late T. aman harvest, late water recede, clay soil and soil moisture depleted rapidly also Prevails problem for vegetable production. In this area after $\mathrm{T}$. aman harvest vegetable cultivation is very difficult because of soil moisture high at as a result this time is not suitable for vegetable and Quick Growing Fruits (QGF) cultivation. After that soil moisture is decreasing day by day and at maturity stage it's damaged by heavy rainfall and early flush flood through tidal surges during post monsoon dry season.

Tillage with planting systems could be a one option to increase yields by farmers in the southern region of Bangladesh during post monsoon dry season. Tillage and planting systems facilitate drainage and aeration in all soil types which reduces seedling rot, promotes rapid root development (Murshner, 1993). Water harvesting techniques achieved through different tillage systems would help in moisture conservation, thus improving growth and yield of tomatoes.

Tillage and planting system is a practice which changes the soil properties, environment and crop production. Tillage techniques are used in order to provide a good seed bed, root development, 
Basher et al.

weed control and manage crop residues, leveling the surface for uniform irrigation and incorporation of manures and fertilizers (Cabeda, 1984).

The research effort on residual effect of tillage with planting system on subsequent crop yields of different vegetables and fruits have not been reported. Therefore, the present study was initiated to evaluate the effective and efficient tillage system for growing upland crops during post monsoon dry season in the southern region of Bangladesh.

\section{Materials and Methods}

The study was conducted at Patuakhali sadar $\left(22^{\circ} 20^{\prime} \mathrm{N}, 90^{\circ} 20^{\prime} \mathrm{E}\right)$ and Dumki $\left(22^{\circ} 25^{\prime} \mathrm{N}, 9^{\circ} 21^{\prime}\right.$ E), Patuakhali district and Jhalokhathi sadar $\left(22^{\circ} 41^{\prime} \mathrm{N}, 90^{\circ} 12^{\prime} \mathrm{E}\right)$, Jhalokhathi district in the southern coastal region of Bangladesh under farmers' field condition during the dry season (after wet season rice harvest) of 2011-2012. The experiment was laid out at randomized complete block design (RCBD) with two factors having six dispersed replications (one farmer's field was considered as one replication) in three different locations. Factor A; three tillage system i.e. two pass, three pass and four pass were done with country plough following cross pass and factor B; two types of planting method i.e. bed planting and flat planting. The unit plot size was $8 \mathrm{~m} \times 5 \mathrm{~m}$. The experiment was repeated with four crops namely, tomato (BARI tomato-14), brinjal (BARI begun-4), bitter gourd (Tia) and cucumber (Naogaon-green). The experimental plots were fertilized following the Krishi Projukti Hatboi (BARI, 2011). The fertilizer rate for brinjal was: 175 $\mathrm{kg} \mathrm{ha}^{-1} \mathrm{~N}, 50 \mathrm{~kg} \mathrm{ha}^{-1} \mathrm{P}, 180 \mathrm{~kg} \mathrm{ha}^{-1} \mathrm{~K}, 13 \mathrm{~kg} \mathrm{ha}^{-1} \mathrm{~S}$ and $10 \mathrm{t} \mathrm{ha}{ }^{-1}$ Cowdung, tomato was: 140 $\mathrm{kg} \mathrm{ha-1} \mathrm{N}, 40 \mathrm{~kg} \mathrm{ha}^{-1} \mathrm{P}, 130 \mathrm{~kg} \mathrm{ha}^{-1} \mathrm{~K}, 13 \mathrm{~kg} \mathrm{ha}^{-1} \mathrm{~S}$ and $10 \mathrm{t} \mathrm{ha}-1$ Cowdung, bitter gourd was: $65 \mathrm{~kg} \mathrm{ha}^{-1} \mathrm{~N}, 21 \mathrm{~kg} \mathrm{ha}^{-1} \mathrm{P}, 10 \mathrm{~kg} \mathrm{ha}^{-1} \mathrm{~K}, 5 \mathrm{~kg} \mathrm{ha}^{-1} \mathrm{~S}, 1.0 \mathrm{~kg} \mathrm{ha}^{-1} \mathrm{Zn}$ and $3 \mathrm{t} \mathrm{ha}{ }^{-1}$ Cowdung and cucumber was: $50 \mathrm{~kg} \mathrm{ha}^{-1} \mathrm{~N}, 17 \mathrm{~kg} \mathrm{ha}^{-1} \mathrm{P}, 12 \mathrm{~kg} \mathrm{ha}^{-1} \mathrm{~K}, 6 \mathrm{~kg} \mathrm{ha}^{-1}$ gypsum, $1.0 \mathrm{~kg} \mathrm{ha}^{-1} \mathrm{Zn}$ and 5 ton ha-1 Cowdung. Thirty days old seedlings of the crops were transplanted on 11 to 14 December 2011 for tomato and brinjal. Bittergourd and cucumber seed were sown directly after prepared the bed i.e; $1^{\text {st }}$ week of January 2012. Marketable ripening fruits of tomato were harvested from 25 February to 18 March 2012. Brinjal harvesting was done from 07 March to 20 April 2012. Bitter gourd was started 70-75 DAS and cucumber was 45-50 DAS. Fertilizer application method and other agronomic practices were done as per Krishi Projukti Hatboi (BARI, 2011). All agronomic and environmental data were recorded carefully. Soil moisture data were recorded at 20 days interval 0ver the experimental period.

\section{Results and Discussion}

\section{Effect of tillage on brinjal}

Yield and yield attributes of brinjal affected by tillage systems were sown in Table 1 . The highest number of fruits plant ${ }^{-1}$ was found in 2 passes of tillage and it was increased with increasing the number of tillage. Again individual fruit weight was highest in 4 passes of tillage and it was decreased with decreasing the number of tillage. It might be due to fruit size. Finally the highest fruit yield was obtained from 4 passes of tillage $\left(64.00 \mathrm{t} \mathrm{ha}^{-1}\right)$ followed by 3 passes of tillage (40.15 tha-1).

\section{Effect of planting systems on brinjal}

Planting system was statistically non-significant in yield and all yield contributing traits (Table 2). Planting in bed system was observed in higher in all cases than planting in flat systems. It might 
Tillage and Planting System of Upland Crops

be due to better management and conserved prolonged soil moisture and its escape the tidal surge and early rainfall or flush flood. Planting in bed produced higher fruit yield $\left(44.91 \mathrm{t} \mathrm{ha}^{-1}\right)$ and lower in flat planting system $\left(39.27 \mathrm{t} \mathrm{ha}^{-1}\right)$.

\section{Interaction effect of tillage with planting system on brinjal}

The interaction effect of tillage with planting system was presented in table 3 . Number of fruits plant $^{-1}$ varied significantly among different tillage system. The highest number of fruits plant ${ }^{-1}$ was found in 3 passes of tillage and it was decreased when increased in tillage system. No. of fruits plant $^{-1}$ and individual fruit weight were the most vital characters for contributing fruit yield. From this point of view maximum number of fruits per plant gave small size and lowest number of fruits per plant gave big size fruits. The highest individual fruit weight was observed in 3-4 pass of tillage in both bed and flat planting methods. The highest fruit yield $\left(67.73 \mathrm{t} \mathrm{ha}^{-1}\right)$ was found in 4 passes of tillage with bed next to 4 passes of tillage in flat planting system $\left(60.26 \mathrm{t} \mathrm{ha}^{-1}\right)$. From the interaction it was clear that when tillage passes increased with planting in bed then fruit yield increased. The lowest fruit yield also observed in 2 passes tillage in both planting system.

Table 1. Yield and yield attributes of brinjal as affected by different tillage practices

\begin{tabular}{l|c|c|c}
\hline Treatments & $\begin{array}{c}\text { No. of fruits } \\
\text { plant }\end{array}$ & $\begin{array}{c}\text { Individual fruit wt. } \\
(\mathrm{g})\end{array}$ & $\begin{array}{c}\text { Fruit yield } \\
\left(\mathrm{t} \mathrm{ha}^{-1}\right)\end{array}$ \\
\hline 2 passes of tillage & 40.00 & 21.83 & 22.14 \\
3 passes of tillage & 35.00 & 38.00 & 40.15 \\
4 passes of tillage & 31.67 & 65.66 & 64.00 \\
LSD $_{(0.05)}$ & 4.26 & 7.92 & 6.75 \\
\hline
\end{tabular}

Table 2. Yield and yield attributes of brinjal as affected by different planting system

\begin{tabular}{l|c|c|c}
\hline Treatments & $\begin{array}{c}\text { No. of fruits } \\
\text { plant }^{-1}\end{array}$ & $\begin{array}{c}\text { Individual fruit wt. } \\
(\mathrm{g})\end{array}$ & $\begin{array}{c}\text { Fruit yield } \\
\left(\mathrm{t} \mathrm{ha}^{-1}\right)\end{array}$ \\
\hline Planting in bed & 36.11 & 45.77 & 44.91 \\
Planting in flat system & 35.00 & 37.88 & 39.27 \\
T-test & NS & NS & NS \\
\hline
\end{tabular}

Table 3. Interaction of planting system and tillage practices on the yield and yield attributes of brinjal

\begin{tabular}{cl|c|c|c}
\hline Treatments & $\begin{array}{c}\text { No. of fruits } \\
\text { plant }\end{array}$ & $\begin{array}{c}\text { Individual fruit wt. } \\
(\mathrm{g})\end{array}$ & $\begin{array}{c}\text { Fruit yield } \\
\left(\mathrm{t} \mathrm{ha}^{-1}\right)\end{array}$ \\
\hline \multirow{2}{*}{$\begin{array}{c}\text { Planting in } \\
\text { bed }\end{array}$} & 2 passes of tillage & 40.00 & 23.33 & 23.44 \\
& 3 passes of tillage & 35.00 & 43.33 & 43.56 \\
\hline \multirow{2}{*}{ Planting in } & 2 passes of tillage & 33.33 & 70.66 & 67.73 \\
\multirow{2}{*}{ flat system } & 3 passes of tillage & 40.00 & 20.33 & 20.83 \\
& 4 passes of tillage & 35.00 & 32.66 & 36.73 \\
LSD $(0.05)$ & 30.00 & 60.66 & 60.26 \\
CV (\%) & 3.03 & 4.40 & 4.07 \\
\hline
\end{tabular}

\section{Effect of tillage on tomato}

Yield and yield attributes of tomato affected by tillage systems were sown in Table 4 . The highest number of fruits plant ${ }^{-1}$ was found in 4 passes of tillage and it was decreased with decreasing the number of tillage. Again individual fruit weight was highest in 3 passes of tillage and it was same 
Basher et al.

to the 4 passes of tillage. Finally the highest fruit yield was obtained from 4 passes of tillage $\left(81.50 \mathrm{t} \mathrm{ha}^{-1}\right)$ followed by 3 passes of tillage (59.16 $\left.\mathrm{t} \mathrm{ha}^{-1}\right)$.

\section{Effect of planting systems on tomato}

Planting system was statistically non-significant in yield and all yield contributing traits (Table 5). Planting in bed system was observed in higher in all cases than planting in flat systems. It might be due to better management and conserved prolonged soil moisture and its escape the tidal surge and early rainfall or flush flood. Planting in bed produced higher fruit yield $\left(59.11 \mathrm{t} \mathrm{ha}^{-1}\right)$ and lower in flat planting system $\left(50.22 \mathrm{t} \mathrm{ha}^{-1}\right)$.

\section{Interaction effect of tillage with planting system on tomato}

The interaction effect of tillage with planting system was presented in Table 6. Number of fruits plant ${ }^{-1}$ varied significantly among different tillage system. The highest number of fruits plant ${ }^{-1}$ was found in 4 passes of tillage and it was decreased when decreased in tillage system in both flat and bed planting system. No. of fruits plant ${ }^{-1}$ and individual fruit weight were the most vital characters for contributing fruit yield. From this point of view maximum number of fruits plant ${ }^{-1}$ gave small size and lowest number of fruits plant ${ }^{-1}$ gave big size fruits. The highest individual fruit weight was observed in 3-4 pass of tillage in both bed and flat planting systems. The highest fruit yield (85.33 $\mathrm{t} \mathrm{ha}^{-1}$ ) was found in 4 passes of tillage with bed next to 4 passes of tillage in flat planting system (77.66 t ha-1). From the interaction it was clear that when tillage passes increased with planting in bed then fruit yield increased. The lowest fruit yield also observed in 2 passes tillage in both bed and flat planting syste.

Table 4. Yield and yield attributes of tomato as affected by different tillage practices

\begin{tabular}{|c|c|c|c|}
\hline Treatments & No. of fruits plant ${ }^{-1}$ & Individual fruit wt. (g) & Fruit yield (t ha-1) \\
\hline 2 passes of tillage & 10.83 & 71.50 & 23.33 \\
\hline 3 passes of tillage & 22.17 & 78.33 & 59.16 \\
\hline 4 passes of tillage & 27.66 & 77.33 & 81.50 \\
\hline $\operatorname{LSD}_{(0.05)}$ & 3.68 & 5.32 & 6.82 \\
\hline
\end{tabular}

Table 5. Yield and yield attributes of tomato as affected by different planting system

\begin{tabular}{lcccc}
\hline Treatments & No. of fruits plant & Individual fruit wt. (g) & Fruit yield (t ha $\left.{ }^{-1}\right)$ \\
\hline Planting in bed & 22.00 & 76.66 & 59.11 \\
Planting in flat system & 18.44 & 74.77 & 50.22 \\
T-test & NS & NS & NS \\
\hline
\end{tabular}

Table 6. Interaction of planting system and tillage practices on the yield and yield attributes of tomato

\begin{tabular}{ll|c|c|c}
\hline Treatments & $\begin{array}{c}\text { No. of fruits } \\
\text { plant }^{-1}\end{array}$ & $\begin{array}{c}\text { Individual fruit wt. } \\
(\mathrm{g})\end{array}$ & $\begin{array}{c}\text { Fruit yield } \\
\text { (t ha-1) }\end{array}$ \\
\hline Planting in & 2 passes of tillage & 11.00 & 72.33 & 26.33 \\
bed & 3 passes of tillage & 25.33 & 78.66 & 65.66 \\
& 4 passes of tillage & 29.66 & 79.00 & 85.33 \\
\hline Planting in & 2 passes of tillage & 10.66 & 70.66 & 20.33 \\
flat system & 3 passes of tillage & 19.00 & 78.00 & 52.66 \\
& 4 passes of tillage & 25.66 & 75.66 & 77.66 \\
\hline LSD $_{(0.05)}$ & & 2.87 & 2.97 & 1.30 \\
$\mathrm{CV}(\%)$ & 3.57 & 11.13 & 5.32 \\
\hline
\end{tabular}


Tillage and Planting System of Upland Crops

\section{Effect of tillage on bitter gourd}

Effect of tillage practices on the yield of bitter gourd was presented in Table 7. Tillage practices are one of the most important parts of management practices and it contributes to the yield. There was no significant difference in number of fruits per plant. Again, individual fruit weight was highest in 4 passes of tillage and lowest in 2 passes of tillage. Regarding yield it was found that when 4 passes of tillage was used then maximum fruit yield $\left(40.15 \mathrm{t} \mathrm{ha}^{-1}\right)$ was found and lowest in 2 passes of tillage $\left(24.05 \mathrm{t} \mathrm{ha}^{-1}\right)$. Reason might be behind that maximum tillage retained moisture in the soil and crop can survive for longer period, which was ultimately produced maximum fruit yield.

\section{Effect of planting system on bitter gourd}

Effect of planting systems on the yield of bitter gourd was presented in Table 8. There was no significant difference in no. of fruits plant ${ }^{-1}$ and individual fruit weight. Planting in bed produced higher fruit yield $\left(32.80 \mathrm{t} \mathrm{ha}^{-1}\right)$ and lower in flat planting system $\left(30.33 \mathrm{t} \mathrm{ha}^{-1}\right)$. It was due to number of fruits plant ${ }^{-1}$, individual fruit weight also higher in bed planting system. Another bed planting systems conserved prolonged soil moisture and its escape the tidal surge and early rainfall or flush flood.

\section{Interaction effect of tillage with planting system on bitter gourd}

Interaction effect of tillage practices and planting system was presented in Table 9. Number of fruits plant ${ }^{-1}$ varied significantly among different tillage system. Highest number of fruits plant ${ }^{-1}$ was found in 2-3 passes of tillage and it was decreased when increased in tillage system in both bed and flat planting system. No. of fruits plant ${ }^{-1}$ and individual fruit weight were the most vital characters for contributing fruit yield. From this point of view maximum number of fruits plant ${ }^{-1}$ gave small size and lowest number of fruits plant ${ }^{-1}$ gave big size fruits. The highest individual fruit weight was observed in 4 passes of tillage in both bed and flat planting system. From the interaction it was clear that highest fruit yield $\left(41.8 \mathrm{t} \mathrm{ha}^{-1}\right)$ was found in 4 passes of tillage with bed planting system. The second highest fruit yield $\left(38.5 \mathrm{t} \mathrm{ha}^{-1}\right)$ was obtained from planting in flat system with 4 passes of tillage. Flat planting with 2 passes of tillage gave the lowest fruit yield $\left(22.9 \mathrm{t} \mathrm{ha}^{-1}\right)$. Low yield in 2 passes of tillage was probably due to low moisture content of the soil which causes early ripening along with smaller size of fruits, ultimately lower yield. Again, in case of bed planting system plant survive in many days due to escaping early flush flood or rainfall. Whereas, planting in flat system plant damage when early rainfall occurs that is later stage of harvest in March to April.

\section{Effect of tillage on cucumber}

Effect of tillage practices on the yield of cucumber was presented in Table 10. Tillage practices are one of the parts of management practices and it contributes to the yield. Number of fruits plant $^{-1}$, individual fruit weight was highest in 4 passes of tillage and it was lowest in 2 passes of tillage. Non significant variation was observed in individual fruit weight. Regarding yield it was found that when 4 passes of tillage was used then maximum fruit yield $\left(24.3 \mathrm{t} \mathrm{ha}^{-1}\right)$ was found and lowest in 2 passes of tillage $\left(14.2 \mathrm{t} \mathrm{ha}^{-1}\right)$. Reason might be behind that maximum tillage retained moisture in the soil and crop can survive for longer period, which was ultimately produced maximum fruit yield. 
Basher et al.

Table 7. Yield and yield attributes of bitter gourd as affected by different tillage practices

\begin{tabular}{l|c|c|c}
\hline Treatments & $\begin{array}{c}\text { No. of fruits } \\
\text { plant }^{-1}\end{array}$ & $\begin{array}{c}\text { Individual fruit wt. } \\
(\mathrm{g})\end{array}$ & $\begin{array}{c}\text { Fruit yield } \\
\left(\mathrm{t} \mathrm{ha}^{-1}\right)\end{array}$ \\
\hline 2 passes of tillage & 20.50 & 198.50 & 24.05 \\
3 passes of tillage & 20.80 & 201.35 & 30.50 \\
4 passes of tillage & 20.60 & 209.80 & 40.15 \\
LSD $_{(0.05)}$ & NS & 6.04 & 5.63 \\
\hline
\end{tabular}

Table 8. Yield and yield attributes of bittergourd as affected by different planting system

\begin{tabular}{l|c|c|c}
\hline Treatments & $\begin{array}{c}\text { No. of fruits } \\
\text { plant }^{-1}\end{array}$ & $\begin{array}{c}\text { Individual fruit wt. } \\
(\mathrm{g})\end{array}$ & $\begin{array}{c}\text { Fruit yield } \\
\left(\mathrm{t} \mathrm{ha}^{-1}\right)\end{array}$ \\
\hline Planting in bed & 20.67 & 203.50 & 32.80 \\
Planting in flat system & 20.37 & 202.90 & 30.33 \\
T-test & NS & NS & $*$ \\
\hline
\end{tabular}

The mean yield loss $(\mathrm{M}=2.47, \mathrm{SD}=0.764, \mathrm{~N}=3)$ was significantly greater than zero, $\mathrm{t}(2)=5.59$, two-tail $\mathrm{p}=0.03$, providing evidence that the bed planting is effective in increase fruit yield. A $95 \%$ C. I. about mean fruit yield increase is $(0.57$, 4.37)

Table 9. Interaction of planting system and tillage practices on the yield and yield attributes of bitter gourd

\begin{tabular}{ll|c|c|c}
\hline Treatments & $\begin{array}{c}\text { No. of fruits } \\
\text { plant }^{-1}\end{array}$ & Individual fruit wt. $(\mathrm{g})$ & $\begin{array}{c}\text { Fruit yield } \\
\left(\mathrm{t} \mathrm{ha}^{-1}\right)\end{array}$ \\
\hline Planting in & 2 passes of tillage & 21.00 & 199.0 & 25.2 \\
bed & 3 passes of tillage & 21.00 & 201.2 & 31.4 \\
& 4 passes of tillage & 20.70 & 210.3 & 41.8 \\
\hline Planting in & 2 passes of tillage & 20.50 & 198.0 & 22.9 \\
flat system & 3 passes of tillage & 20.60 & 201.5 & 29.6 \\
& 4 passes of tillage & 20.00 & 209.3 & 38.5 \\
\hline LSD $(0.05)$ & & 2.46 & 7.12 & 4.91 \\
CV $(\%)$ & 5.10 & 2.30 & 7.2 \\
\hline
\end{tabular}

\section{Effect of planting system on cucumber}

Effect of planting systems on the yield of cucumber was presented in Table 11. There was no significant difference in no. of fruits plant ${ }^{-1}$. Planting in bed produced higher fruit yield $(20.5 \mathrm{t}$ $\mathrm{ha}^{-1}$ ) and lower in flat planting system. It was due to number of fruits plant ${ }^{-1}$, individual fruit weight also higher in bed planting system. Another bed planting systems conserved prolonged soil moisture and its escape the tidal surge and early rainfall or flush flood.

\section{Interaction effect of tillage practices and planting system on cucumber}

Interaction effect of tillage practices and planting system was presented in Table 12. Number of fruits plant ${ }^{-1}$ varied significantly among different tillage system. The highest number of fruits plant $^{-1}$ was found in 4 passes of tillage and it was decreased with decreased in tillage system in both planting system. The highest individual fruit weight was observed in 3-4 passes of tillage in both bed and flat planting system. The interaction effect showed that highest fruit yield $(25.8 \mathrm{t}$ $\left.\mathrm{ha}^{-1}\right)$ was found in 4 passes of tillage with bed planting system. The next fruit yield $\left(22.8 \mathrm{t} \mathrm{ha}^{-1}\right)$ was obtained from planting in flat system with 4 passes of tillage followed by 3 passes of tillage with planting in bed system. Flat planting with 2 passes of tillage gave the lowest fruit yield (12.9 $\mathrm{t} \mathrm{ha}^{-1}$ ) due to low moisture content of the soil which causes early ripening along with smaller size 
Tillage and Planting System of Upland Crops

of fruits, ultimately lower yield. In case of bed planting system plants survive in many days due to escaping early flush flood or rainfall whereas, planting in flat plant damage when early rainfall occurs later stage of harvest in March to April. From the point of view fruit harvest in long time and it helps to increased fruit yield.

Table 10. Yield and yield attributes of cucumber as affected by different tillage practices

\begin{tabular}{l|c|c|c}
\hline Treatments & $\begin{array}{c}\text { No. of fruits } \\
\text { plant }^{-1}\end{array}$ & $\begin{array}{c}\text { Individual fruit wt. } \\
(\mathrm{g})\end{array}$ & $\begin{array}{c}\text { Fruit yield } \\
\left(\mathrm{t} \mathrm{ha}^{-1}\right)\end{array}$ \\
\hline 2 passes of tillage & 4.77 & 141.26 & 14.2 \\
3 passes of tillage & 5.17 & 142.27 & 19.4 \\
4 passes of tillage & 8.39 & 145.84 & 24.3 \\
LSD $_{(0.05)}$ & 3.12 & $\mathrm{NS}$ & 2.78 \\
\hline
\end{tabular}

Table 11. Yield and yield attributes of cucumber as affected by different planting system

\begin{tabular}{l|c|c|c}
\hline Treatments & $\begin{array}{c}\text { No. of fruits } \\
\text { plant }^{-1}\end{array}$ & $\begin{array}{c}\text { Individual fruit wt. } \\
(\mathrm{g})\end{array}$ & $\begin{array}{c}\text { Fruit yield } \\
\left(\mathrm{t} \mathrm{ha}^{-1}\right)\end{array}$ \\
\hline Planting in bed & 6.29 & 143.46 & 20.5 \\
Planting in flat system & 5.92 & 142.79 & 18.1 \\
T-test & NS & $*$ & $*$ \\
\hline
\end{tabular}

The mean individual fruit weight loss $(\mathrm{M}=2.4, \mathrm{SD}=0.721, \mathrm{~N}=3)$ was significantly greater than zero, $\mathrm{t}(2)=8.67$, two-tail $\mathrm{p}=0.01$, providing evidence that the bed planting is effective in increase individual fruit weight. A $95 \% \mathrm{C}$. I. about mean individual fruit weight increase is $(0.33,0.99)$

The mean fruit yield loss $(\mathrm{M}=0.67, \mathrm{SD}=0.133, \mathrm{~N}=3)$ was significantly greater than zero, $t(2)=5.76$, two-tail $p=0.03$, providing evidence that the bed planting is effective in increase fruit yield. A $95 \%$ C. I. about mean fruit yield increase is $(0.61,4.19)$

Table 12. Interaction of planting system and tillage practices on the yield and yield attributes of cucumber

\begin{tabular}{ll|c|c|c}
\hline Treatments & $\begin{array}{c}\text { No. of fruits } \\
\text { plant }^{-1}\end{array}$ & $\begin{array}{c}\text { Individual fruit wt. } \\
(\mathrm{g})\end{array}$ & $\begin{array}{c}\text { Fruit yield } \\
\text { (t ha-1) }\end{array}$ \\
\hline Planting in & 2 passes of tillage & 4.88 & 141.52 & 15.5 \\
bed & 3 passes of tillage & 5.33 & 142.62 & 20.2 \\
& 4 passes of tillage & 8.66 & 146.23 & 25.8 \\
\hline Planting in & 2 passes of tillage & 4.66 & 141.00 & 12.9 \\
flat system & 3 passes of tillage & 5.00 & 141.92 & 18.6 \\
& 4 passes of tillage & 8.11 & 145.45 & 22.8 \\
LSD $_{(0.05)}$ & & 2.89 & 2.99 & 1.45 \\
$\mathrm{CV}(\%)$ & 3.85 & 10.13 & 4.22 \\
\hline
\end{tabular}

\section{Effects of tillage on soil moisture}

The soil moisture content insignificantly influenced due to different tillage and planting methods (Fig. 1). In the whole growing season, the maximum soil moisture was noted on four pass of tillage system followed by three and two pass of tillage system. Actually soil moisture gradually decreased with time. Again, in last sampling, there was no significant difference among the tillage treatments due to heavy rainfall in the months of March 2012. Soil moisture content changed due to tillage practices and higher moisture content was observed in four pass of tillage practice at whole growing season of tomato, brinjal, bitter gourd and cucumber. These results 
Basher et al.

were similar to Bonari et al. (1994) and Bhatt et al. (2004) stated that soil moisture contents are substantially higher with chisel plowing than minimum tillage.

$$
\begin{array}{ll}
\square \text { Flat } 2 \text { passes } & \text { Flat } 3 \text { passes } \\
\square \text { Flat } 4 \text { passes } & \square \text { Bed } 2 \text { passes } \\
\square \text { Bed } 3 \text { passes } & \square \text { Bed } 4 \text { passes }
\end{array}
$$

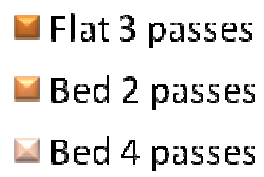

Flat 3 passes

$\square$ Bed 2 passes

$\triangle$ Bed 4 passes
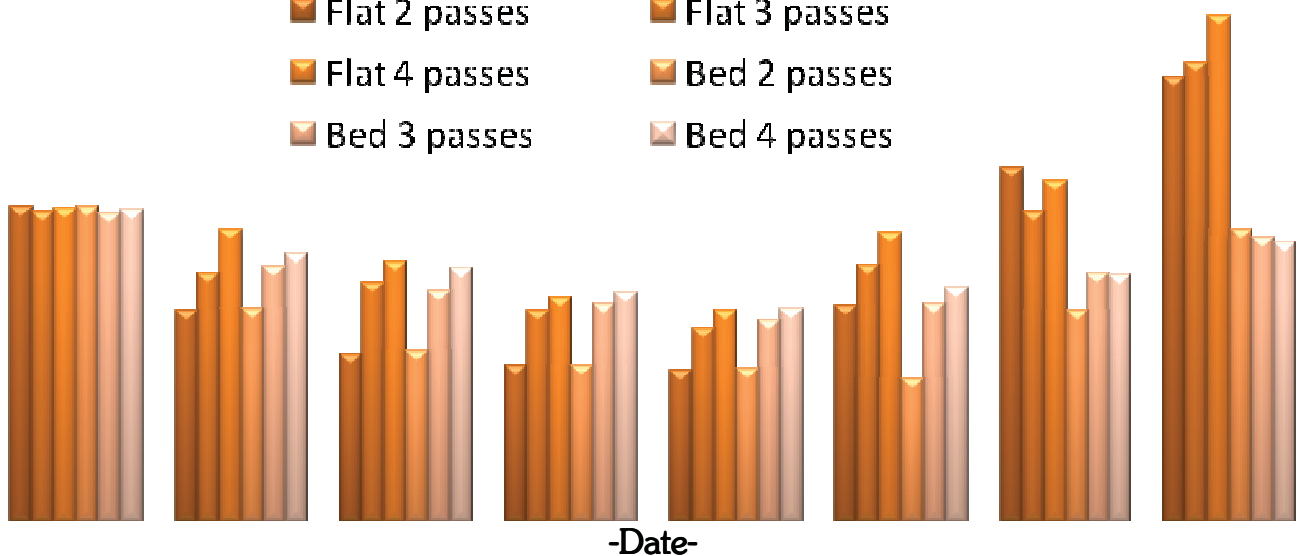

Fig. 1. Soil moisture content (\%) at different tillage and planting method

Cogle et al. (1997) reported that deep tillage increase the soil porosity and manipulate surface roughness to improve water intake. Meherban and Chaudhury (1998) also observed that deep tillage decreased soil bulk density and penetration resistance up to the tilled depth $40 \mathrm{~cm}$ and encourage root growth more in the deeper soil layer and increase water holding capacity.

\section{Conclusion}

Above the study, it is noted that clear that after T. aman harvest in medium high land for growing upland crops during dry season bed planting system with 3-4 passes of tillage is the best method and its escaping the tidal surge or early flash flood. The maximum soil moisture was noted on 4 passes of tillage system followed by 3 and 2 passes tillage system. Two passes system showed low moisture content of the soil which causes early ripening along with smaller fruit size ultimately lower yield.

\section{Acknowledgement}

The research was carried out with the financial support of Krishi Gobeshona Foundation (KGF), Bangladesh Agricultural Research Council (BARC), Dhaka, Bangladesh.

\section{References}

BARC (Bangladesh Agricultural Research Council). 2005. Fertilizer Recommendation Guide-2005, BARC, Soils Pub., No. 45, Bangladesh Agril Res Council, Farmgate, Dhaka.

BARI (Bangladesh Agricultural Research Institute). 2011. Krishi Projukti Hat Boi. $5^{\text {th }}$ edition. Bangladesh Agricultural Research Institute, Gazipur 1701, Bangladesh. 
Tillage and Planting System of Upland Crops

Bhatt, R., K. L. Khera and S. Arora. 2004. Effect of tillage and mulching on yield of corn in the submontaneousrainfed region of Punjab, India. Intl. J. Agric. Biol. 6: 126-128.

Bonari, E., M. Mazzoncini, N. Silvestri, M. Pagliai, M. Barbafieri, M. Borin and M. Sattin. 1994. Effects of different soil tillage systems on soil physical characteristics and crop yield. Paper presented at the 3rd Cong EuropSocAgron, Padova University, Abano-Padova, Italy, 18-22 September 1994.

Bhuiya Z. H. 1987 Organic matter status and organic recycling in Bangladesh soils. Res. Conserv. Recycl. 13: 117-124.

Cogle, A. L., K. P. C. Rao, D. F. Yule, P. J. George, S. T. Srinivasan, G. D. Smith and L. Jangawad. 1997. Soil management options for Alfisol in the semi-arid tropics: annual and perennial crop production. Soil Tillage Res. 44: 235-253.

Cabeda. 1984. Effect of tillage on soil physical properties.E. Giasson Soil Dept. The Federal University of Riograde Do Shl Porto Algere, Brazil.

Meherban, S and M. R. Chaudhury. 1998. Effect of deep tillage on growth and yield of maize under water stress condition at different physiological stages on course textural soils. J. Indian Soc. Soil Sci. 46: 557-562.

Murshner, H. 1993. Mineral nutrition of Higher plants. Institute of plant nutrition. University of Hohenheim, Federal Republic of Germany Academic Press. pp.226-235. 